\title{
TINJAUAN PENGETAHUAN SISWA KELAS XII TERHADAP USAHA KESEHATAN SEKOLAH (UKS) DI SMK PERTANIAN TERPADU NEGERI PROVINSI RIAU
}

\author{
Leni Apriani \\ Universitas Islam Riau \\ Leniapriani24@yahoo.com
}

\begin{abstract}
ABSTRAK
Tujuan dari penelitian ini adalah untuk mengetahui tingkat pengetahuan siswa terhadap Usaha Kesehatan Sekolah (UKS) di SMK Pertanian Terpadu Negeri Provinsi Riau. Adapun teknik pengambilan data yang dipergunakan dalam penelitian ini observasi, angket dan studi kepustakaan. Populasi dalam penelitian ini adalah seluruh siswa kelas XII SMK Pertanian Terpadu Negeri Privinsi Riau sebanyak 130 orang. Sampel adalah 63 orang terdiri dari XII ROMBEL A-E. Hasil penelitian ini menunjukkan bahwa pengetahuan Siswa Kelas XII terhadap usaha kesehatan sekolah di SMK Pertanian Terpadu Negeri Provinsi Riau terutama pada bidang Trias UKS yang di peroleh skor rata-rata jawaban sampel penelitian 50,76\% dinyatakan kurang baik. Hal ini salah satu faktor kurangnya guru penjaskesrek memberikan pembelajaran kesehatan secara terprogram sehingga pengetahuan siswa terhadap UKS kurang baik.
\end{abstract}

Kata Kunci : Tinjauan Pengetahuan Siswa Kelas XII Terhadap (UKS) Di SMK Pertanian Terpadu Negeri Provinsi Riau.

\section{PENDAHULUAN}

Kegiatan olahraga juga merupakan salah satu bentuk dari kependidikan. pendidikan jasmani merupakan rangkaian aktivias jasmani, bermain dan berolahraga, untuk membangun peserta didik yang sehat dan kuat sehingga dapat menghasilkan prestasi akedemik yang tinggi. Pendidikan jasmani kesehatan yang dilakukan sejak dini merupakan awal pengembangan prestasi olahraga. Hal ini menunjukkan betapa pentingnya pembinaan pendidikan jasmani, baik melalui jalur sekolah maupun luar sekolah.

Pendidikan jasmani kesehatan sangat penting dan berguna bagi anak didik. Pendidikan jasmani kesehatan terdapat materi usaha kesehatan sekolah, yang mana usaha kesehatan sekolah sangat berperan di setiap jenjang pendidikan formal. Kesehatan anak didik akan diperhatikan oleh guru-guru yang tergabung dalam struktur usaha kesehatan sekolah, karena kesehatan anak sangat mempengaruhi kegiatan belajar anak didik.

Sekolah secara formal merupakan wadah pembinaan, pelayanan dan pelaksanaan progran usaha kesehatn sekolah (UKS) dan kegiatan lainya. Usaha kesehatan sekolah (UKS) adalah salah satu langkah yang efektif untuk melaksanakan 
pembinaan karena masyarakat sekolah memiliki persentase tinggi yang peka terhadap pendidikan.

Undang-Undang No. 9 tahun 1960 Tentang pokok-pokok kesehatan Bab I pasal 2 disebutkan bahwa pengertian sehat atau kesehatan adalah sebagai berikut: Kesehatan yang meliputi kesehatan fisik, mental, dan sosial, dan bukan hanya keadaan yang bebas dari penyakit, cacat dan kelemahan.

Pendidikan tidak akan sempurna dan lengkap tanpa pendidikan jasmani dan rohani disamping memiliki pengetahuan dan keterampilan teknis dibidang olahraga. Siswa juga mempunyai nilai-nilai sosial yang positif serta dapat menanamkan landasan yang kuat untuk membentuk sifat-sifat sportifitas yang tinggi sesuai dengan tujuan pendidikan. Salah satu materi dalam kurikulum pendidikan jasmani yang di pelajari dalam jenjang pendidikan adalah usaha kesehatan sekolah (UKS).

Dalam pembelajaran pendidikan olahraga dan kesehatan jasmani ada terdapat materi pembelajaran tentang Pendidikan Jasmani Kesehatan sebagai berikut: (a) Usaha kesehatan sekolah (UKS), (b) Narkoba, (c) Seks bebas (d) Bahaya HIV/AIDS (e) Pemanfaatan waktu luang untuk kesehatan dan lain sebagainya. Dalam pembelajaran di Sekolah, guru akan menjelaskan tentang kesehatan jasmani itu terhadap anak muridnya. Dengan pemberian materi pendidikan kesehatan jasmani maka siswa dapat mengetahui dampak positif dan negativ yang akan di timbulkan oleh pembelajaran tersebut. (Irwansyah:2006).

Dengan anak mengetahui apa pentingnya dalam mempelajari pendidikan kesehatan terutama pada materi pembelajaran usaha kesehatan sekolah anak akan memahami bagaimana usaha pemeliharaan kesehatan sekolah, pelaksanaan usaha kesehatan sekolah, dan petugas pelaksanaan sekolah.

Berdasarkan penjelasan di atas, dapat disimpulkan bahwa sekolah mulai dari Sekolah Dasar hingga Sekolah Menengah Atas merupakan lembaga pendidikan yang berperan bukan hanya memberikan bekal pengetahuan bagi peserta didik, melainkan meningkatkan derajat kesehatan bagi siswa-siswinya. Salah satu sarana dan prasarana terwujudnya budaya hidup sehat di sekolah adalah melalui usaha kesehatan sekolah (UKS).

Mengingat pentingnya UKS ditiap-tiap sekolah bisa dibayangkan program UKS tidak dilaksanakan atau tidak sama sekali. Tanpa adanya pembelajaran materi pembelajaran UKS peserta didik akan menjadi siswa yang buta akan kesehatan, tidak mengerti akan pentingnya lingkungan sehat, dan tidak memahami prilaku hidup sehat. Upaya-upaya pemeliharaan dan peningkatan kesehatan yang bertujuan untuk mencapai kemampuan hidup sehat bagi seluruh penduduk harus dimulai sejak dini.

Berdasarkan hasil pengamatan dilapangan pengetahuan siswa-siswi yang ada di Sekolah SMK Pertanian Terpadu Provinsi Riau, ditemukan beberapa fenomena atau gejala antara lain: 1) kurangnya pengetahuan siswa tentang UKS. 2) Minimnya sarana dan prasarana UKS di sekolah SMK Pertanian Terpadu Negeri Provinsi Riau. 3) Kurangnya peranan guru penjas terhadap kegiatan UKS. 4) Kurangya materi pembelajan UKS yang di berikan oleh guru penjas berdasarkan kurikulum. 5) Kurangnya aplikasi siswa terhadap UKS.

Di mana kegiatan pembelajaran UKS belum berjalan dengan baik. Seandainya hal ini tidak diatasi, tentu tujuan dari usaha kesehatan sekolah tidak akan tercapai dan anak didik akan peka terhadap pengetahuan UKS tersebut. Dengan demikian hal ini dapat dipergunakan untuk mencari kemampuan siswa dalam pembelajaran pendidikan 
jasmani dalam materi UKS sehingga dalam pengembangan akan berjalan dengan baik. Sejalan dengan itu, untuk membuktikan kebenaran itulah penulis ingin mendapatkna jawaban dan pemecahan masalah diatas perlu diadakan penelitian dengan judul: Tinjauan Pengetahuan Siswa Kelas XII Terhadap Usaha Kesehatan Sekolah di SMK Pertanian Terpadu Negeri Provinsi Riau.

\section{HASIL DAN PEMBAHASAN}

\section{A. Hakikat Usaha Kesehatan Sekolah (UKS)}

\section{1) Pengertian UKS}

Berdasarkan analisis yang telah dilakukan mengenai data Pengetahuan Siswa Kelas XII Terhadap Usaha Kesehatan Sekolah Di SMK Pertanian Terpadu Negeri Provinsi Riau terutama pada bidang Trias UKS yang di peroleh skor rata-rata jawaban sampel penelitian 50,76\% dinyatakan Kurang Baik. Hal ini salah satu faktor kurangnya diberikan pembelajaran kesehatan secara terprogram yang di berikan oleh guru penjas sehingga pengetahuan siswa terhadap UKS akan kurang. Hal tersebut sesuai dengan kurikulum KTSP Kelas XI semester II. Guru penjas lebih banyak terfokus pada praktek olahraga, sehingga pembelajaran tentang kesehatan tidak tercapai atau secara teori. Sesuai dengan wawancara penulis dengan guru penjas.

Pengertian akan kesehatan sangat luas, karena kesehatan tidak hanya meliputi kesehatan rohani dan sosial. Dalam Undang-Undang No. 9 tahun 1960 Pokok-pokok kesehatan, bab I, pasal 2, yang dimaksud dengan kesehatan meliputi kesehatan badan, rohani (mental) dan sosial dan bukan hanya keadaan bebas dari penyakit, cacat dan kelemahan.

Poernomo (1981:30), menyatakan bahwa program Usaha Kesehatan sekolah (UKS) meliputi 3 program utama yaitu. 1) Lingkungan kehidupan sekolah yang sehat, 2) Pendidikan atau penyuluhan kesehatan, 3) Pelayanan kesehatan di sekolah,

R.J. Soenarjo (2002:4) menyatakan bahwa "Usaha Kesehatan Sekolah (UKS) ialah usaha kesehatan masyarakat yang dijalankan di sekolah-sekolah, dengan sasaran utama anak-anak sekolah dan lingkunganya ". Irwansyah (2006) Pendidikan Jasmani, Olahraga dan Kesehatan SMA Kelas XI menyatakan bahwa "Usaha Kesehatan Sekolah adalah bagian dari usaha kesehatan masyarakat yang dijalankan di sekolah-sekolah dengan melibatkan anak didik, guru dan lingkungan hidupnya sebagai sasaran utama.

Menurut pendapat diatas, bahwa faktor yang besar pengaruhnya terhadap pertumbuhan dan perkembangan jasmani, rohani dan sosial anak didik dan penghuni lainya di sekolah. lingkungan kehidupan yang sehat merupakan unsur yang harus dikembangkan agar pendidikan mencapai hasil yang diharpkan. Kebersihan sangat berarti dalam kehidupan sehari-hari terutama pada ank didik yang berada di sekolah. Dengan lingkungnan dan hidup yang bersih anak akan lebih baik dalam melaksanakan belajar. Jadi anak didik harus di upayakan hidup sehat.

Pendidikan tidak akan sempurna dan lengkap tanpa pendidikan jasmani dan rohani disamping memiliki pengetahuan dan keterampilan teknis dibidang olahraga. Siswa juga mempunyai nilai-nilai sosial yang positif serta dapat menanamkan landasan yang kuat untuk membentuk sifat-sifat sportifitas yang tinggi sesuai dengan tujuan pendidikan. Salah satu materi dalam kurikulum pendidikan jasmani yang di pelajari dalam jenjang pendidikan adalah Usaha Kesehatan Sekolah (UKS). Dengan anak mengetahui apa pentingnya dalam mempelajari pendidikan kesehatan terutama pada materi pembelajaran Usaha Kesehatan Sekolah (UKS) anak akan memahami 
bagaimana usaha pemeliharaan kesehatan sekolah, pelaksanaan usaha kesehatan sekolah, dan petugas pelaksanaan sekolah.

Alatas (2002) Ilmu Kesehatan Anak menyatakan bahwa Usaha kesehatan sekolah diadakan dinegara kita mengingat beberapa hal, diantaranya ialah :

1. Anak golongan umur sekolah(6-18 tahun) merupakan masyarakat yang jumlahnya besar dan sebagian di antara mereka telah dapat tertampung di sekolah.

2. Anak didalam golongan ini masih dalam taraf pertumbuhan dan perkembangan, hingga masih mudah dibimbing dan dibina untuk untuk menanamkan kebiasaan hidup sehat sehari-hari dengan harapan mereka dapat meneruskan kebiasaan sehat ini dan juga dapat mempengaruhi lingkungan hidupnya.

3. Anak sekolah merupakan masyarakat besar yang berkumpul hingga mudah dicapai dalam rangka pelaksanaan berbagai kesehatan.

4. Masyarakat sehat untuk masa mendatang ditentukan terutama oleh pengertian sikap dan kebiasaan hidup sehat yang dimiliki oleh anak generasi sekarang.

5. Disamping itu sekolah dipandang sebagai lembaga yang dengan sengaja dihidupkan untuk mempertinggi derajat masyarakat dengan segala seginya dan guru sebagai tenaga penggeraknya.

Menanamkan kebiasan hidup sehat dan mendorong anak didik untuk ikut serta dalam berbagai usaha kesehatan serta ikut bertanggung jawab atas kesehatanya sendiri atau lingkunganya.

\section{2) Tujuan UKS}

Tujuan Usaha Kesehatan Sekolah (UKS) adalah salah satu wahana untuk meningkatkan kemampuan hidup sehat dan derajat kesehatan peserta didik sedini mungkin. Tujuan umum Usaha Kesehatan Sekolah (UKS) adalah meningkatkan kemampuan hidup sehat dan derajat kesehatan peserta didik serta menciptakan lingkungan yang sehat, sehingga memungkinkan pertumbuhan dan perkembangan yang harmonis dan optimal dalam rangka pembentukan manusia indonesia seutuhnya. Setiap organisasi, apapun bentuknya memiliki tujuan-tujuan yang ingin dicapai. Begitu juga halnya dengan Usaha Kesehatan Sekolah (UKS).

Depdiknas (2005:6) menyatakan bahwa "Tujuan Usaha Kesehatan Sekolah (UKS) adalah untuk meningkatkan mutu pendidikan dan prestasi belajar peserta didik dengan meningkatkan prilaku hidup bersih dan sehat dan derajat kesehatan peserta didik maupun warga belajar serta menciptakan lingkungan yang sehat, sehingga memungkinkan pertumbuhan dan perkembangan yang harmonis dan optimal dalam rangka pembentukan manusia indonesia seutuhnya".

Dengan adanya program dan tujuan dari UKS maka anak didik akan lebih baik lagi dalam menerima pembelajaran, dikarenakan anak didik dalam keadaan yang sehat. Disini dapat kita lihat betapa pentingnya peranan UKS dalam dunia pendidikan untuk menghasilkan mutu pendidikan yang lebih baik.

Sedangkan secara khusus tujuan Usaha Kesehatan Sekolah (UKS) rumusan Depdiknas (2005:6) adalah untuk memupuk kebiasaan sehat dan mempertinggi derajat kesehatan peserta didik yang didalamnya mencakup: 1) Memiliki pengetahuan, sikap dan keterampilan untuk melaksanakan prinsip hidup sehat, serta berpartisipasi aktif didalam usaha peningkatkan kesehatan disekolah dan perguruan agama, rumah tangga 
maupun dilingkungan masyarakat. 2) Sehat, baik arti fisik, maupun mental, sosial maupun lingkungan, dan 3) Memiliki daya hayat dan daya tangkap terhadap pengaruh buruk, penyalahgunaan narkoba, alkohol dan kebiasaan merokok serta hal-hal yang berkaitan dengan masalah pornografi dan masalah sosial lainya.

Tujuan pendidikan Usaha Kesehatan Sekolah (UKS) ini adalah menanamkan kebiasaan hidup sehat kepada anak didik agara dapat turut bertanggung jawab terhadap kesehatan dirinya serta lingkunganya dan ikut aktif dalam usaha-usaha kesehatan. Apabila anak didik telah dapat mempraktekkan kebiasan sehat sehari-hari ini dalam hidupnya, maka dapat diharapkan bahwa disamping untuk dirinya sendiri, mereka dapat pula mempengaruhi dan membimbing masyarakat lingkunganya.

\section{3) Petugas Pelaksana UKS}

Pelaksana Usaha Kesehatan Sekolah ialah seseorang yang berdasarkan fungsi, tugas dan kewajibanya berhubungan dengan anak didik dan lingkungan sekolah. Petugas UKS biasa di lakukan oleh seorang guru sebagai pembina dari UKS dan anak didik yang melaksanakan tugas dan menjaga UKS yang biasanya di bimbing oleh guru di sekolah.

Alatas (2002:61), Disamping petugas kesehatan, guru mempunyai peranan yang sangat penting di dalam pelaksana Usaha Kesehatan Sekolah, mengingat bahwa gurulah yang setiap hari menghadapi anak didik dan mengikuti pertumbuhan, perkembangan serta keadaan kesehatan anak didiknya. Para pelaksanan Usaha Kesehatan Sekolah terdiri dari: a) Peranan Petugas Kesehatan, b) Peranan Guru, c) Peranan Anak Didik, d) Peranan Orang Tua Murid.

\section{4) Ruang Lingkup Pembinaan UKS}

Poernomo (1981:30), menyatakan bahwa program Usaha Kesehatan sekolah (UKS) meliputi 3 program utama yaitu. 1) Lingkungan kehidupan sekolah yang sehat, 2) Pendidikan atau penyuluhan kesehatan, 3) Pelayanan kesehatan di sekolah, yang selanjutnya lebih dikenal dengan istilah Trias Program Usaha Kesehatan Sekolah (UKS).

\section{METODOLOGI PENELITIAN}

Penelitian ini dilakukan dengan menggunakan metode penelitian deskriptif. Populasi dalam penelitian ini adalah seluruh siswa kelas XII SMK Pertanian Terpadu Negeri Privinsi Riau yang berjumlah 130 orang. Adapun Sampelnya adalah sebahagian populasi yang diteliti (Suharsimi, Arikunto, 1998:120). Adapun teknik pengambilan sampel dalam penelitian ini adalah dengan menggunakan random sampling, yaitu teknik penentuan sampel penelitian secara acak dan sengaja. Maka didapat sampel dalam penelitian ini berjumlah 63 orang siswa SMK Pertanian Terpadu Negeri Provinsi Riau.

\section{a. Teknik Pengumpulan Data}

Adapun teknik pengambilan data yang dipergunakan dalam penelitian ini yaitu sebagai berikut :

1. Observasi yaitu dengan mengadakan pengamatan secara langsung bagaimana pengetahuan siswa dalam pembelajaran Usaha Kesehatan Sekolah (UKS) di SMK Pertanian Terpadu Negeri Propinsi Riau. 
2. Angket. Cara ini dilakukan dengan cara mengajukan berupa daftar pertanyaan kepada responden yang menjadi objek penelitian. Cara ini untuk mendapatkan data yang sekuler.

Setelah data terkumpul dari angket, data tersebut diolah dengan menggunakan rumus:

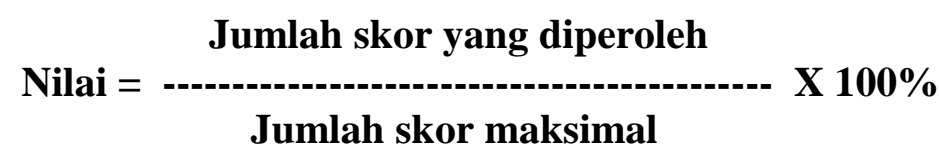

Nilai komulatif

Rumus : $P=\frac{F}{N} \times 100 \%$

Keterangan :

$\mathrm{P} \quad=$ Persentase

$\mathrm{F} \quad=$ Frekuensi

$\mathrm{N} \quad=$ Jumlah Responden

Dalam menentukan kriteria dilakukan pengelompokan atas 4 kriteria penilaian yaitu sangat baik, baik, cukup baik dan tidak baik, hal ini mengacu pada pendapat Suharsimi Arikunto (1996:246). Adapun kriteria persentase tersebut yaitu sebagai berikut :

1) Persentase antara $76 \%$ - 100\% dikatakan "Baik"

2) Persentase antara 56\% - 75\% dikatakan "Cukup"

3) Persentase antara $40 \%$ - 55\% dikatakan Kurang Baik"

4) Persentase kurang dari $40 \%$ dikatakan "Tidak Baik"

\section{b. Deskriptif Data}

Berdasarkan permasalahan yang telah di uraikan sebelumnya, maka data yang diolah dalam penelitian ini adalah data tentang Tinjauan Pengetahuan Siswa Kelas XII Terhadap Usaha Kesehatan Sekolah Di SMK Pertanian Terpadu Negeri Provinsi Riau. Data tersebut akan disajikan melalui tabel-tabel. Sesuai dengan yang telah disebutkan bahwa hasil penelitian ini akan di deskripsikan dan di analisa serta di interpretasikan secara deskriptif.

\section{a) Tinjauan Pengetahuan Siswa Kelas XII Terhadap Lingkungan Kehidupan} Sekolah Yang Sehat Di SMK Pertanian Terpadu Negeri Provinsi Riau

Data Pengetahuan Siswa Kelas XII Terhadap Lingkungan Kehidupan Sekolah yang Sehat Di SMK Pertanian Terpadu Negeri Provinsi Riau, mengenai Trias UKS diperoleh dari 10 soal pada angket penelitian yang dijawab oleh 63 orang sampel penelitian dengan hasil yang tertera pada tabel 1 berikut ini: 
Tabel 1. Distribusi Frekuensi Data Pengetahuan Siswa Kelas XII Terhadap Lingkungan Kehidupan Sekolah Yang Sehat Di SMK Pertanian Terpadu Negeri Provinsi Riau.

\begin{tabular}{cccc}
\hline No & Nilai & Frekuensi & Persentase (\%) \\
\hline 1 & 8 & 3 & 4,76 \\
2 & 7 & 6 & 9,52 \\
3 & 6 & 12 & 19,04 \\
4 & 5 & 19 & 30,15 \\
5 & 4 & 13 & 20,63 \\
6 & 3 & 10 & 15,87 \\
\hline Jumlah & & $\mathbf{6 3}$ & $\mathbf{1 0 0 \%}$
\end{tabular}

Sumber : Data Olahan 2011

Berdasarkan tabel diatas, di peroleh data terbesar 10 dan data terkecil 1 , menghasilkan rata-rata (mean) 5, data yang sering muncul (mode) 5, data tengah (median) 5,5 dan range 6.

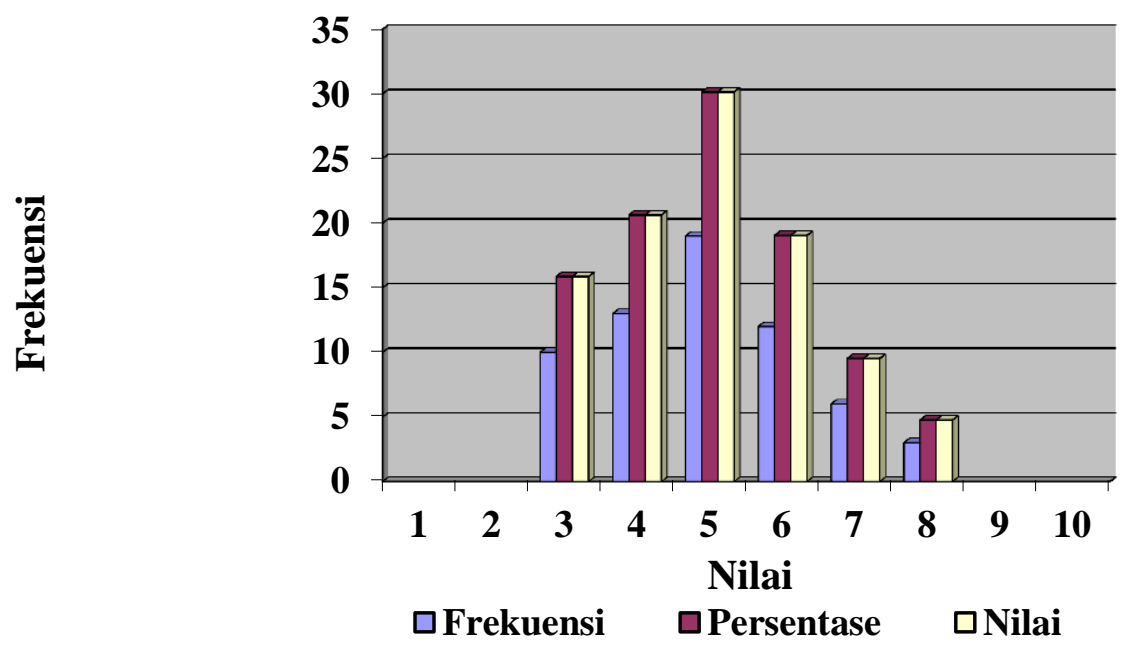

Gambar 1: Diagram Batang Pengetahuan Siswa Kelas XII Terhadap Lingkungan Kehidupan Sekolah Yang Sehat Di SMK Pertanian Terpadu Negeri Provinsi Riau

b) Tinjauan Pengetahuan Siswa Kelas XII Terhadap Pendidikan Atau Penyuluhan Kesehatan Di SMK Pertanian Terpadu Negeri Provinsi Riau

Data Pengetahuan Siswa Kelas XII Terhadap Pendidikan Atau Penyuluhan Kesehatan Di SMK Pertanian Terpadu Negeri Provinsi Riau, mengenai Trias UKS diperoleh dari 10 soal pada angket penelitian yang dijawab oleh 63 orang sampel penelitian dengan hasil yang tertera pada tabel 2 berikut ini: 
Tabel 2. Distribusi Frekuensi Data Pengetahuan Siswa Kelas XII Terhadap Pendidikan Atau Penyuluhan Kesehatan Di SMK Pertanian Terpadu Negeri Provinsi Riau.

\begin{tabular}{cccc}
\hline No & Nilai & Frekuensi & Persentase (\%) \\
\hline 1 & 7 & 7 & 11,11 \\
2 & 6 & 15 & 23,80 \\
3 & 5 & 17 & 26,98 \\
4 & 4 & 15 & 23,80 \\
5 & 3 & 8 & 12,69 \\
6 & 2 & 1 & 1,58 \\
\hline & Jumlah & $\mathbf{6 3}$ & $\mathbf{1 0 0 \%}$ \\
\hline
\end{tabular}

Sumber : Data Olahan 2011

Berdasarkan tabel diatas, di peroleh data terbesar 10 dan data terkecil 1, menghasilkan rata-rata (mean) 5,31, data yang sering muncul (mode) 5, data tengah (median) 4,5 dan range 6.

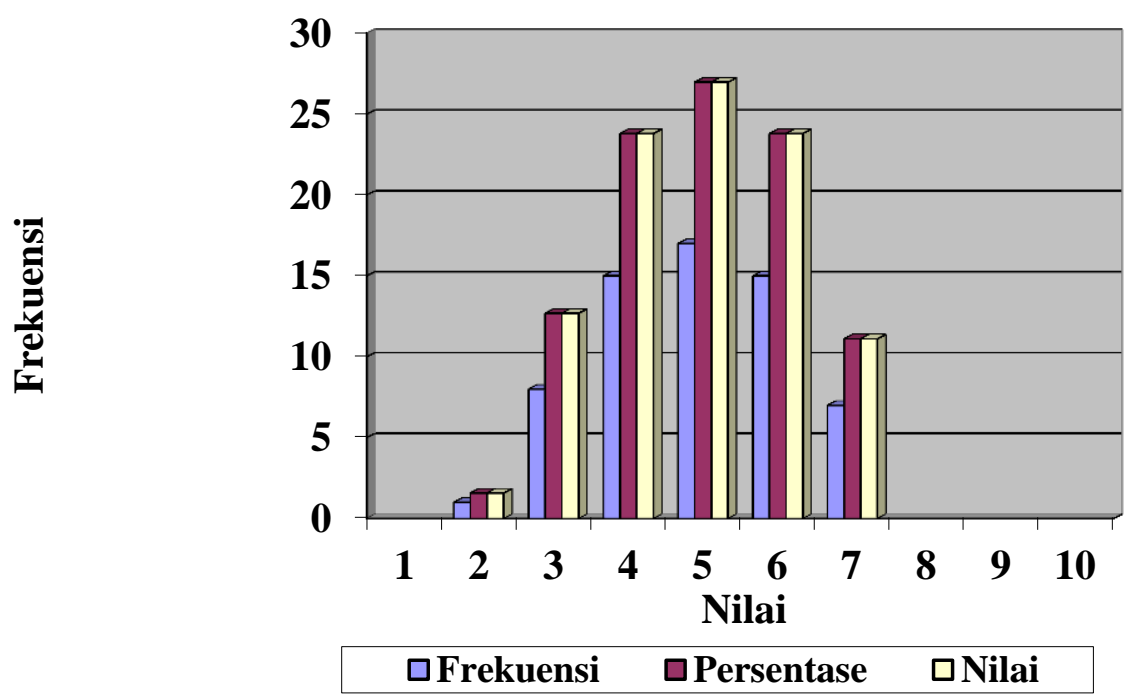

Gambar 2: Diagram Batang Pengetahuan Siswa Kelas XII Terhadap Pendidikan Atau Penyuluhan Kesehatan Di SMK Pertanian Terpadu Negeri Provinsi Riau

c) Tinjauan Pengetahuan Siswa Kelas XII Terhadap Pelayanan Kesehatan Di Sekolah Di SMK Pertanian Terpadu Negeri Provinsi Riau

Data Pengetahuan Siswa Kelas XII Terhadap Pelayanan Kesehatan Di Sekolah Di SMK Pertanian Terpadu Negeri Provinsi Riau, mengenai Trias UKS diperoleh dari 10 soal pada angket penelitian yang dijawab oleh 63 orang sampel penelitian dengan hasil yang tertera pada tabel 3 berikut ini: 
Tabel 3. Distribusi Frekuensi Data Pengetahuan Siswa Kelas XII Terhadap Pelayanan Kesehatan Di Sekolah Di SMK Pertanian Terpadu Negeri Provinsi Riau.

\begin{tabular}{cccc}
\hline No & Nilai & Frekuensi & Persentase $(\boldsymbol{\%})$ \\
\hline 1 & 8 & 1 & 1,58 \\
2 & 7 & 12 & 19,04 \\
3 & 6 & 17 & 26,98 \\
4 & 5 & 11 & 17,46 \\
5 & 4 & 14 & 22,22 \\
6 & 3 & 8 & 12,69 \\
\hline Jumlah & & $\mathbf{6 3}$ & $\mathbf{1 0 0 \%}$ \\
\hline
\end{tabular}

Sumber : Data Olahan 2011

Berdasarkan tabel diatas, di peroleh data terbesar 10 dan data terkecil 1, menghasilkan rata-rata (mean) 5,22, data yang sering muncul (mode) 6, data tengah (median) 5 dan range 6 .

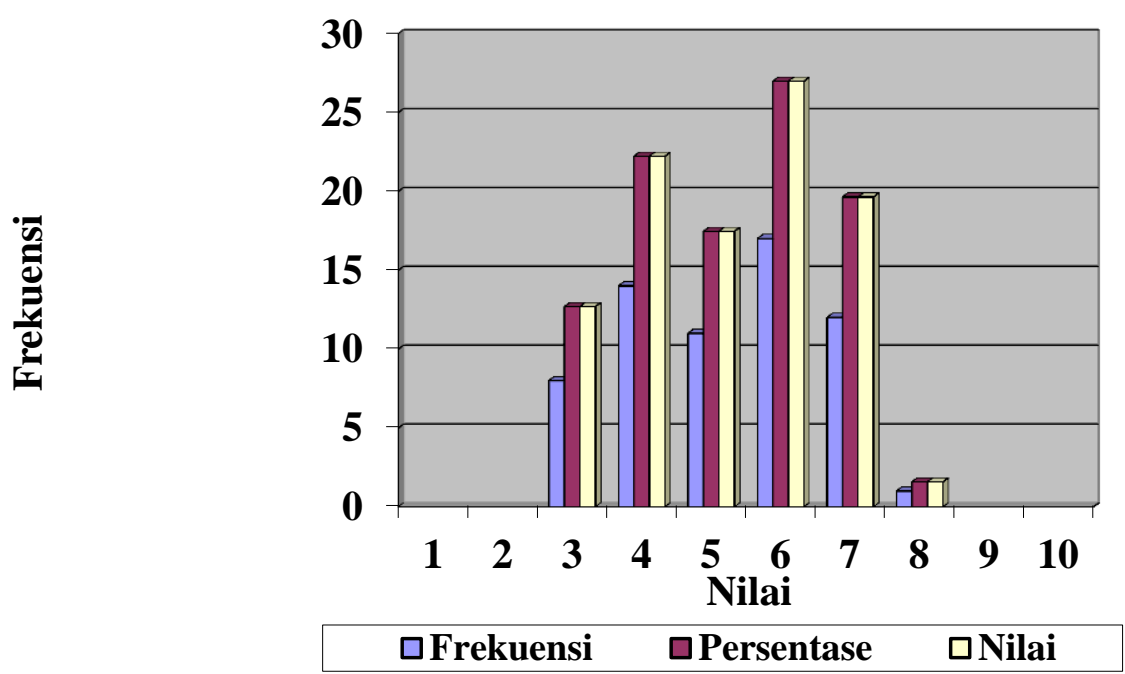

Gambar 3: Diagram Batang Pengetahuan Siswa Kelas XII Terhadap Pelayanan Kesehatan Di Sekolah Di SMK Pertanian Terpadu Negeri Provinsi Riau

\section{c. Analisa Data}

Data Pengetahuan Siswa Kelas XII Terhadap Trias UKS diperoleh dari 30 soal pada angket penelitian yang dijawab oleh 63 orang sampel penelitian dengan hasil yang tertera pada tabel 4 berikut ini: 
Tabel 4. Distribusi Frekuensi Data Pengetahuan Siswa Kelas XII Terhadap Usaha Kesehatan Sekolah Di SMK Pertanian Terpadu Negeri Provinsi Riau.

\begin{tabular}{cccc}
\hline No & Interval Nilai & Frekuensi & Persentase (\%) \\
\hline 1 & $68,4-73,3$ & 4 & 6,38 \\
2 & $63,4-68,3$ & 5 & 7,93 \\
3 & $58,4-63,3$ & 10 & 15,87 \\
4 & $55,4-58,3$ & 6 & 9,52 \\
5 & $48,4-53,3$ & 12 & 19,04 \\
6 & $43,4-48,4$ & 3 & 4,76 \\
7 & $38,4-43,3$ & 11 & 17,47 \\
8 & $33,3-38,9$ & 12 & 19,04 \\
\hline
\end{tabular}

Sumber : Data Olahan 2011

Berdasarkan tabel diatas, di peroleh data terbesar 73,3 dan data terkecil 33,3, menghasilkan rata-rata (mean) 50,76, data yang sering muncul (mode) 50,85, data tengah (median) 53,3 dan range 50. Berdasarkan distribusi frekuensi data di peroleh skor rata-rata 50,76\%. Dapat di lihat pada lampiran 4.

Dari data di atas, alternatif jawaban yang benar dengan nilai 1 dan jawaban yang salah dengan nilai 0 , maka dari 30 butir soal, skor maksimum ideal adalah 30/30 x 100 $=100$ dan skor minimum adalah 0. Berdasarkan distribusi frekuensi data di peroleh skor rata-rata 50,76\%, maka diperoleh nilai sebesar 50,76\%. Disimpulkan bahwa, Tingkat Pengetahuan Siswa Kelas XII Terhadap Usaha Kesehatan Sekolah Di SMK Pertanian Terpadu Negeri Provinsi Riau di kategorikan Kurang Baik.

\section{KESIMPULAN}

Berdasarkan hasil penelitian dan analisa data yang telah dilakukan maka dapat di tarik kesimpulan bahwa : Tingkat Pengetahuan Siswa Kelas XII Terhadap Usaha Kesehatan Sekolah (UKS) Di SMK Pertanian Terpadu Negeri Provinsi Riau di kategorikan Kurang Baik.

\section{DAFTAR PUSTAKA}

Alatas, Husein. 2002. Ilmu Kesehatan Anak. Jakarta,.Infomedika.

Arikunto, Suharsimi. (2002). Prosedur Penelitian. Bandung: CV Tarsto.

Depkes. (1995). Usaha Kesehatan Sekolah Petunjuk Teknis Penjaringan Kesehatan di Sekolah. Jakarta.

Depdiknas. (2006). Pedoman Pembinaan Dan Pengembangan Usaha Kesehatan Sekolah (UKS). Jakarta.

Depdiknas. (2007). Pedoman Penilaian Hasil Belajar Di Sekolah Dasar. Jakarta: Derektorat Jenderal Manajemen Pendidikan Dasar Dan Menengah. 
Irwansyah. (2006). Pendidikan Jasmani, Olahraga, dan Kesehatan SMA Kelas XI. Bandung: Grafindo.

Poernomo, Sonja. (1981). Kesehatan di Sekolah Indonesia. Jakarta: Firman Resema.

R.J. Soenarjo. (2002). Usaha Kesehatan Sekolah. Bandung: PT Remaja Rosdakarya.

Sudijono, Anas. (2004). Pengantar Statistik Pendidikan. Bandung: Alfabeta.

Suharto dan Sonti. (2000). Pendidikan Kesehatan untuk Sekolah Dasar Kelas 4. Jakarta: Depdikbud.

Tamat, Tisnowati. (2002). Pendidikan Kesehatan dan Jasmani. Jakarta: UT.

Yandianto. (2000). Kamus Umum Bahasa Indonesia. Bandung: M2S. 